\title{
Prevalence of Human Immunodeficiency Virus and Malaria Co-Infection in Nigeria: A Review of Published Literature
}

\author{
Omotayo S. Alaofin ${ }^{1} \&$ Kantharuben Naidoo ${ }^{2}$ \\ ${ }^{1}$ Discipline of Public Health Medicine, School of Nursing and Public Health, University of KwaZulu-Natal, \\ Durban, South Africa \\ ${ }^{2}$ Discipline of Family Medicine, School of Nursing and Public Health, University of KwaZulu-Natal, Durban, \\ South Africa \\ Correspondence: Omotayo S. Alaofin, Department of public health medicine, University of KwaZulu-Natal, \\ Durban 4001, South Africa. Tel: 27-78-052-8980. Fax: 27-031-260-4465. E-mail: alaofinomotayo@gmail.com
}

Received: August 21, 2019 Accepted: September 9, 2019 Online Published: November 30, 2019

doi:10.5539/gjhs.v12n1p30 URL: https://doi.org/10.5539/gjhs.v12n1p30

\begin{abstract}
Background: Human immunodeficiency virus and malaria are significant global health challenges. Both diseases contribute to the global burden of disease and poverty notable amongst low-income countries, including sub-Sahara Africa and Nigeria. There are little or no available review articles on the prevailing epidemiological data on human immunodeficiency virus and malaria interaction in Nigeria.
\end{abstract}

Aim: This literature review aims to update knowledge on human immunodeficiency virus and malaria co-infection and determine the prevalence of human immunodeficiency virus and malaria from published literature.

Method: This work reviewed published articles on human immunodeficiency virus/malaria co-infection published in English in PubMed, Google Scholar, and ScienceDirect. An internet search on Google Scholar was also conducted for studies that were conducted between 2007 and 2017 in Nigeria.

Result: The literature review indicated that the highest prevalence of human immunodeficiency virus and malaria co-infection in Nigeria is $86.2 \%$. The mean \pm SD among the HIV-malaria co-infected group and the negative malaria group in all of Nigeria's geo-political zones are $36.6 \pm 25.5$ and $19.5 \pm 15.3$, respectively. The highest mean prevalence of $64.5 \%$ was reported in human immunodeficiency virus patients co-infected with malaria in the northwest zone. The use of highly active antiretroviral therapy is also associated with a reduced mean positive prevalence of $31.26 \%$.

Conclusion: Human immunodeficiency virus-positive individuals across all the geopolitical zones in Nigeria are at high risk of malaria. Findings from this review of literature will provide additional information on HIV-malaria co-infection prevalence and guide public health prevention, control and management practice.

Keywords: HIV, malaria, co-infection, prevalence, adults, treatment, Nigeria

\section{Introduction}

Human Immunodeficiency Virus (HIV) and malaria are a significant health challenge (World Health Organization, 2005). Globally, there is a rapid increase in the population of HIV seropositive individuals from 31.0 million in 2002 to an estimated 35.3 million in 2012 (UNAIDS, 2013) with an approximately 36.7 million including 2.1 million (1.8-2.4) newly reported cases worldwide at the end of 2016 (WHO, 2016a).

The prevalence of global malaria cases fell by $18 \%$ from approximately 262 million to 212 million cases between the years 2000 and 2015 (WHO, 2016b). About 216 million malaria cases were reported at the end of 2016 (95\% Confidence Interval (CI): 196-263 million), in contrast to approximately 237 million cases documented in 2010 (95\% CI: 218-278 million) (WHO, 2017). Approximately half of the global population (3.2 billion people) are still at risk of malaria (WHO, 2016b), largely in the tropics and South East Asia, a region where both diseases overlap (Hochman Sarah \& Kim Kami, 2009).

Over the years, positive progress has been made to speed up HIV and malaria control and preventive programme. Remarkable decrease in Human Immunodeficiency Virus and Acquired Immune Deficiency Syndrome (HIV/AIDS) morbidity and mortality has been reported since the initiation of Highly Active Antiretroviral 
Therapy (HAART). However, severe and repeated malaria cases were documented among HIV positive patients on HAART and Artemisinin-based Combination Therapy (ACT) (Nakanjako, Kiragga, Castelnuovo, Kyabayinze, \& Kamya, 2011). Co-infection interaction between malaria and HIV encourages the proliferation of both infectious diseases, coupled with an increased risk of HIV transmission and multiple episodes of severe malaria (Cuadros \& García-Ramos, 2012). Furthermore, it was believed that interaction between HIV and malaria is expected to have a significant impact on prevention and management practices and further leads to decreased control efforts (WHO, 2016c).

The prevalence of HIV-malaria co-infection is based on the pattern of malaria transmission, which differs in developed and developing countries. Therefore, data on prevalence from high-income countries cannot be generalized to low-income countries, especially in the sub-Saharan African (SSA) region, including Nigeria. Findings from studies on the prevalence of HIV-malaria co-infection conducted in SSA, as well as in Nigeria, revealed several differences due to geographical variation. The prevalence reported from selected studies conducted in SSA ranges from $0.7 \%$ to $72 \%$ and $2.11 \%$ to $86.2 \%$ among studies conducted in Nigeria.

\subsection{Purpose of the Literature Review}

The purpose of this review of the published article is to update the knowledge of HIV-malaria co-infection and determine the prevalence of HIV-malaria co-infection in Nigeria.

\section{Method}

\subsection{The Search Strategy of the Literature Review/Data Collection}

This literature review involves an extensive search of databases such as PubMed, Google Scholar, ScienceDirect, and a general internet search for related studies that were conducted for over ten years. Reference sections in journal articles and studies that reported HIV-malaria co-infection prevalence (and vice versa) were also reviewed to find other relevant studies. Studies included in this review are those conducted in Nigeria.

\subsection{HIV and Malaria Co-Infection}

A high level of co-infection interaction occurs mainly in sub-Saharan Africa, where the immune deficiency posed by HIV supports malaria disease and transmission, which may affect malaria control efforts (Whitworth et al., 2000). Malaria on the other hand, increases HIV replication, progression, and transmission (Focà, Odolini, Brianese, \& Carosi, 2012; Van geertruyden, 2014), and the severity of malaria cases in HIV positive individuals usually depends on malaria prevalence in the general population. HIV-malaria co-infection is highly influenced by the local HIV prevalence, malaria endemicity, and transmission. This is responsible for the heterogeneous distribution of co-infections in regions where both disease overlap (UNAIDS).

\subsection{HIV-Malaria Co-Infection Interaction Among Adults}

HIV-malaria co-infection interaction is responsible for an increase in clinical cases of severe malaria among adults, including children and pregnant women (Hochman Sarah \& Kim Kami, 2009). The combined effect increases the viral load and decreases CD4+ T-cell counts, together with a decrease in the production of antibodies and cytokines (Hochman Sarah \& Kim Kami, 2009). Previous studies have documented that the resulting viral load is higher among women with placental malaria. Infants of co-infected mothers are at high risk of premature birth, decreased birth weight, and death, compared to infants born of mothers who are only HIV seropositive. Malaria in pregnant adults is also responsible for increased blood viral load, breast milk, and decreased CD4 T-cell count, which increases the risk of transmitting the virus to the children (Laufer \& Plowe, 2007). The efficacy of malaria chemotherapy is lower in non-pregnant HIV positive adults than in those who are HIV seronegative (Khoo, Back, \& Winstanley, 2005). Higher malaria density is common among male HIV seropositive individuals than their female counterparts, which may be associated with more severe immunosuppression in infected male individuals (Iroezindu et al., 2012).

\subsection{Prevalence of HIV and Malaria Co-Infection in Nigeria}

According to the Joint United Nations Programme on HIV and AIDS (UNAIDS) 2014, Nigeria accounted for more than $9 \%$ of global HIV positive individuals (Unaids Facts Sheet 2014, Global Statistics), which is the nation with the second-largest global HIV epidemic. Despite having an adult HIV prevalence of approximately $2.9 \%$ at the end of 2017 (NACA, 2017), and a 15\% decrease in new HIV cases since 2005 (UNAIDS, 2017). Approximately two-thirds of all HIV cases in the central and west African regions occur in Nigeria (UNAIDS, 2017). It currently accounts for more than 3.6 million global HIV positive individuals and one of the highest rates of new HIV cases in the SSA region (NACA, 2017). According to the 2017 UNAIDS report, an estimated 3.2 million people lived with HIV and Acquired Immune Deficiency Syndrome (AIDS) in Nigeria, with more than 
220000 new cases annually (UNAIDS, 2017). Nigeria has an estimated 3.1\% adult's prevalence of HIV-1 between 15-49 years (NACA, 2015), with an estimated 3.5 million adults being HIV seropositive (UNAIDS, 2016).

Over 100 million individuals are at high risk of malaria in Nigeria (WHO, 2012). Approximately half of the adult population experiences at least one malaria infection, while under-five children are at risk of multiple annual malaria episodes (WHO, 2012). Similarly, malaria is responsible for approximately 51 million hospital admissions and 207,000 mortalities every year, higher than any other country where there is a high prevalence of malaria (WHO, 2012). The country also accounts for $25 \%$ of all malaria cases in the Africa sub-region (WHO, 2012). Malaria is not only an important public health problem but also constitutes a serious community and financial burden in affected countries (Carnivale \& Mouchet, 2011). In Nigeria, malaria is endemic across all ecological zones, and the peak transmission period is during the rainy season, usually between July and December (Salako \& Obi, 1997).

Studies conducted in Nigeria have shown diversity in the spread and distribution of HIV malaria co-infection. There is variation in co-infection prevalence documented in studies conducted in Nigeria, according to groups, populations, and regions. The prevalence of HIV-malaria co-infection among HIV seropositive individuals in Nigeria ranges from $2.11 \%$ to $86.2 \%, 2 \%$ to $44.67 \%$ among HIV negative individuals, and $3.53 \%$ to $68.6 \%$ among pregnant individuals. Similarly, a significant association has been documented between CD4 T-cell count less than 200, and a high risk of anaemia in HIV-malaria co-infected patients. P. falciparum malaria is associated with the majority of malaria cases among HIV positive individuals (Jegede et al., 2017).

\subsection{Effect of HIV-Malaria Co-Infection in Nigeria}

The separate physiological and public health impact of malaria among HIV positive patients cannot be underestimated. The combined effects of HIV and malaria co-infection contributes to more than two million deaths worldwide annually (Mukandavire, Gumel, Garira, \& Tchuenche, 2009; WHO, 2016a). Abu-Raddad et al. (2006) observed that approximately 980,000 new malaria cases and 8,500 excess HIV infections were attributed to co-infection between the 1980s and 2006 in Kenya (Abu-Raddad, Patnaik, \& Kublin, 2006). In Nigeria, the indirect impact of malaria, such as cost of transportation to the health facility, cost of health care, loss of working hours, absenteeism from work accounted for more than 132 billion Naira loss annually and posed a great danger to the economy (Federal Republic of Nigeria, 2005). In a study conducted among HIV positive outpatients, Akinbo et al. (2009) reported that there was an increased risk of anaemia and malaria among HIV positive individuals (Akinbo, Okaka, Omoregie, Mordi, \& Igbinuwen, 2009). A significant association was also reported between HIV-malaria co-infection and rapid reduction in the Packed Cell Volume (PCV) compared to HIV-positive individuals alone, with a mean PCV of $24.81 \%$ in co-infected patient and $34.81 \%$ in malaria negative HIV patients (Goselle, Onwuliri, \& Onwuliri, 2009).

An important marker to evaluate the effect of malaria parasitaemia among HIV-malaria co-infected individuals is serum iron concentration (Onyenekwe et al., 2008). Findings from previous studies demonstrated that serum iron reduction among HIV-malaria co-infected patients compared to HIV-seropositive malaria negative individuals, similar to what was observed among asymptomatic HIV-malaria co-infected patients, and unlike among symptomatic HIV-malaria co-infected individuals (Onyenekwe et al., 2008). A relatively lower albumin concentration was reported by Gossele et al. 2007 among HIV positive patients (Gossele, Onwuliri, \& Onwuliri, 2007), while congenital malaria was observed among new-borns of co-infected mothers (Eki-Udoko, Sadoh, Ibadin, \& Omoigberale, 2017). Notable impacts of malaria on biochemical indicators were observed among HIV positive patients with a rapid reduction of serum iron (Onyenekwe et al., 2007).

\subsection{Methods of Disease Diagnosis}

\subsubsection{HIV Diagnosis}

The Methods of HIV diagnosis and testing that was used in all the literature reviewed are identical to each other. The HIV diagnostic and testing were carried out according to the standards of the World Health Organization (WHO) and recommendations (The Global Fund, 2016). Two major methods used in detecting the HIV antibody are - the Abbott determine HIV-1/2 test Kits (Abbott Laboratories, USA), and Stat Pak HIV 1-2, Rapid HIV Test kit (Premier Medical Corporation Limited, India).

\subsubsection{Malaria Diagnosis}

As observed from the reviewed literature focusing on the studies that were conducted in Nigeria. Microscopic examination and Rapid Diagnostic Test (RDT) are the most widely used methods for malaria diagnosis. However, the most commonly used method for malaria diagnosis is the microscopic examination. The blood smears were performed by the method described by Warhurst (Warhurst \& Williams, 1996) and were analyzed by making thin 
and thick smear to check for malaria parasites. A drop of blood was added to the RDT malaria kit as a confirmatory test. Although both methods were useful, the thin film was used for the identification of the malaria parasites (Berg et al., 2014).

\subsection{Analysis}

Data were extracted from selected published articles that reported the prevalence of HIV-malaria co-infection (Table 1). Statistical analysis was done with Statistical Package for Social Science (SPSS) version 25.0, and the p-value of $<0.05$ was considered significant. The difference between the means of the HIV-malaria co-infected groups and HIV-malaria negative groups was tested using one-way Analysis of Variance (ANOVA).

Table 1. Overview of selected research studies reporting the prevalence of HIV and malaria co-infection in Nigeria

\begin{tabular}{|c|c|c|c|c|c|c|c|c|c|}
\hline Author & \begin{tabular}{|l} 
Study \\
settings
\end{tabular} & Study design & \begin{tabular}{|l} 
Study \\
populatio \\
n
\end{tabular} & $\begin{array}{l}\text { Sample } \\
\text { size }\end{array}$ & $\begin{array}{l}\text { Gender of } \\
\text { participant } \\
\text { s }\end{array}$ & $\begin{array}{l}\text { HIV-Malar } \\
\text { ia } \\
\text { prevalence }\end{array}$ & $\begin{array}{l}\text { HIV/Neg } \\
\text { ative }\end{array}$ & Other findings & $\begin{array}{l}\text { Treatment } \\
\text { procedure }\end{array}$ \\
\hline $\begin{array}{l}\text { Akinbo } \\
\text { (Akinbo FO } \\
\text { et al., 2013) } \\
\text { Benin City, } \\
\text { Nigeria }\end{array}$ & $\begin{array}{l}\text { Tertiary } \\
\text { hospital }\end{array}$ & Not stated & $\begin{array}{l}\text { HIV } \\
\text { positive } \\
\text { patients }\end{array}$ & 317 & $\begin{array}{l}\text { Both } \\
\text { gender/Adul } \\
\text { ts }\end{array}$ & $9.8 \%$ & Nil & $\begin{array}{l}\text { Reduced prevalence of } \\
\text { HIV-malaria } \\
\text { co-infection was } \\
\text { observed among } \\
\text { patients on HAART. }\end{array}$ & $\begin{array}{l}\text { HAART } \\
\text { /ACT }\end{array}$ \\
\hline $\begin{array}{l}\text { Akinbo } \\
\text { (Akinbo FO } \\
\text { et al., 2016) } \\
\text { Kogi State, } \\
\text { Nigeria NCZ }\end{array}$ & $\begin{array}{l}\text { Secondar } \\
\text { y hospital }\end{array}$ & $\begin{array}{l}\text { Case-control } \\
\text { study }\end{array}$ & $\begin{array}{l}\text { HIV } \\
\text { positive } \\
\text { patients }\end{array}$ & 411 & $\begin{array}{l}\text { Both } \\
\text { gender/Adul } \\
\text { ts }\end{array}$ & $7.8 \%$ & $2 \%$ & $\begin{array}{l}\text { Higher prevalence of } \\
\text { HIV-malaria } \\
\text { co-infection was } \\
\text { observed among patient } \\
\text { on HAART }\end{array}$ & HAART \\
\hline $\begin{array}{l}\text { Akinbo } \\
\text { (Akinbo FO } \\
\text { et al., 2009) } \\
\text { Benin City, } \\
\text { Nigeria }\end{array}$ & $\begin{array}{l}\text { Tertiary } \\
\text { hospital }\end{array}$ & $\begin{array}{l}\text { Case-control } \\
\text { prospective } \\
\text { study }\end{array}$ & $\begin{array}{l}\text { HIV } \\
\text { positive } \\
\text { patients }\end{array}$ & 350 & $\begin{array}{l}\text { Both } \\
\text { gender/Adul } \\
\text { ts }\end{array}$ & $46.0 \%$ & $4.9 \%$ & $\begin{array}{l}\text { A higher prevalence of } \\
\text { co-infection was } \\
\text { reported among } \\
\text { females. }\end{array}$ & Nil \\
\hline $\begin{array}{l}\text { Akinbo } \\
\text { (Akinbo FO } \\
\text { \& Omoregie } \\
\text { R, 2012) } \\
\text { Benin City, } \\
\text { Nigeria }\end{array}$ & $\begin{array}{l}\text { Tertiary } \\
\text { hospital }\end{array}$ & $\begin{array}{l}\text { Cross-section } \\
\text { al study }\end{array}$ & $\begin{array}{l}\text { HIV } \\
\text { positive } \\
\text { patients }\end{array}$ & 285 & $\begin{array}{l}\text { Both } \\
\text { gender/Adul } \\
\text { ts }\end{array}$ & $2.11 \%$ & Nil & $\begin{array}{l}\text { There is an association } \\
\text { between CD4 T-cells, } \\
\text { anaemia, and malaria } \\
\text { among HIV patients. }\end{array}$ & HAART \\
\hline $\begin{array}{l}\text { Ako-Nai } \\
\text { (Ako-Nai AK } \\
\text { et al., 2013) } \\
\text { Akure, } \\
\text { Nigeria }\end{array}$ & $\begin{array}{l}\text { Secondar } \\
\text { y hospital }\end{array}$ & $\begin{array}{l}\text { Prospective } \\
\text { cross-section } \\
\text { al study }\end{array}$ & $\begin{array}{l}\text { Pregnant } \\
\text { women } \\
\text { ANC }\end{array}$ & 3225 & $\begin{array}{l}\text { Pregnant } \\
\text { Adults }\end{array}$ & $3.53 \%$ & Nil & $\begin{array}{l}\text { There is a decreasing } \\
\text { mean of CD4 T-cell } \\
\text { counts among HIV } \\
\text { seropositive } \\
\text { participants. }\end{array}$ & Nil \\
\hline $\begin{array}{l}\text { Dada (Dada } \\
\text { EO, 2015) } \\
\text { Ondo State, } \\
\text { Nigeria }\end{array}$ & $\begin{array}{l}\text { Secondar } \\
\text { y hospital }\end{array}$ & Not stated & $\begin{array}{l}\text { HIV } \\
\text { positive } \\
\text { patients }\end{array}$ & 150 & $\begin{array}{l}\text { Both } \\
\text { gender/Adul } \\
\text { ts }\end{array}$ & $54.5 \%$. & Nil & $\begin{array}{l}\text { High co-infection rate } \\
\text { among females. }\end{array}$ & Nil \\
\hline $\begin{array}{l}\text { Edit (Edet } \\
\text { UO, Ebana } \\
\text { RUB, Etok } \\
\text { CA, \& } \\
\text { Nwamuo LC, } \\
\text { 2016) } \\
\text { Kaduna } \\
\text { Nigeria }\end{array}$ & $\begin{array}{l}\text { Secondar } \\
\text { y hospital }\end{array}$ & Not stated & $\begin{array}{l}\text { HIV } \\
\text { positive } \\
\text { patients }\end{array}$ & 150 & $\begin{array}{l}\text { Both gender } \\
\text { (all age } \\
\text { group) }\end{array}$ & $63.8 \%$ & $44.67 \%$ & $\begin{array}{l}\text { The prevalence of } \\
\text { HIV-malaria } \\
\text { co-infection was high, } \\
\text { but not significant. }\end{array}$ & Nil \\
\hline
\end{tabular}




\begin{tabular}{|c|c|c|c|c|c|c|c|c|c|}
\hline $\begin{array}{l}\text { Iroezindu } \\
\text { (Iroezindu et } \\
\text { al., 2012) } \\
\text { Jos, Nigeria } \\
\text { NCZ }\end{array}$ & $\begin{array}{l}\text { Tertiary } \\
\text { hospital }\end{array}$ & $\begin{array}{l}\text { Cross-section } \\
\text { al study }\end{array}$ & $\begin{array}{l}\text { HIV } \\
\text { positive } \\
\text { patients }\end{array}$ & 100 & $\begin{array}{l}\text { Both } \\
\text { gender/Adul } \\
\text { ts }\end{array}$ & $24 \%$ & $9 \%$ & $\begin{array}{l}\text { High prevalence of } \\
\text { malaria among HIV } \\
\text { positive patients than } \\
\text { their HIV negative } \\
\text { counterpart. }\end{array}$ & Nil \\
\hline $\begin{array}{l}\text { Izuka (Izuka } \\
\text { EO et al., } \\
\text { 2017) } \\
\text { Enugu, } \\
\text { Nigeria }\end{array}$ & $\begin{array}{l}\text { Tertiary } \\
\text { hospital }\end{array}$ & $\begin{array}{l}\text { Longitudinal } \\
\text { cohort study }\end{array}$ & $\begin{array}{l}\text { Pregnant } \\
\text { women } \\
\text { ANC }\end{array}$ & 204 & $\begin{array}{l}\text { Pregnant } \\
\text { adults }\end{array}$ & $68.6 \%$ & $35.3 \%$ & $\begin{array}{l}\text { Higher prevalence of } \\
\text { placental malaria and } \\
\text { anaemia were observed } \\
\text { among HIV positive } \\
\text { women than the } \\
\text { negative control. }\end{array}$ & HAART \\
\hline $\begin{array}{l}\text { Jegede } \\
\text { (Jegede et al., } \\
\text { 2017) } \\
\text { Kano, } \\
\text { Nigeria }\end{array}$ & $\begin{array}{l}\text { Tertiary } \\
\text { hospital }\end{array}$ & $\begin{array}{l}\text { Cross-section } \\
\text { al study }\end{array}$ & $\begin{array}{l}\text { HIV } \\
\text { positive } \\
\text { patients }\end{array}$ & 761 & $\begin{array}{l}\text { Both } \\
\text { gender/Adul } \\
\text { ts }\end{array}$ & $27.7 \%$ & Nil & $\begin{array}{l}\text { A lower prevalence of } \\
\text { co-infection was } \\
\text { documented among } \\
\text { patients on } \\
\text { cotrimoxazole. }\end{array}$ & ART \\
\hline $\begin{array}{l}\text { Onifade } \\
\text { (Onifade AK, } \\
\text { Akanni EO, } \\
\text { \& Mewoyeka } \\
\text { OO, 2007) } \\
\text { Ondo State, } \\
\text { Nigeria }\end{array}$ & $\begin{array}{l}\text { Secondar } \\
\text { y hospital }\end{array}$ & Not stated & $\begin{array}{l}\text { HIV } \\
\text { positive } \\
\text { patients }\end{array}$ & 1410 & $\begin{array}{l}\text { Both gender } \\
\text { (all age } \\
\text { group) }\end{array}$ & $33.50 \%$ & Nil & $\begin{array}{l}\text { There is an association } \\
\text { between co-infection } \\
\text { and gender, with higher } \\
\text { prevalence among the } \\
\text { male. }\end{array}$ & Nil \\
\hline $\begin{array}{l}\text { Ojurongbe } \\
\text { (Ojurongbe } \\
\text { et al., 2014) } \\
\text { Osogbo } \\
\text { Nigeria }\end{array}$ & $\begin{array}{l}\text { Tertiary } \\
\text { hospital }\end{array}$ & Not stated & $\begin{array}{l}\text { HIV } \\
\text { positive } \\
\text { patients }\end{array}$ & 200 & $\begin{array}{l}\text { Both } \\
\text { gender/Adul } \\
\text { ts }\end{array}$ & $18.5 \%$ & Nil & $\begin{array}{l}\text { Reduced PCV was } \\
\text { recorded among } \\
\text { HIV/co-infected areas. }\end{array}$ & Nil \\
\hline $\begin{array}{l}\text { Olaniran } \\
\text { (Olaniran O } \\
\text { et al., 2012) } \\
\text { Ile-Ife, } \\
\text { Nigeria }\end{array}$ & $\begin{array}{l}\text { Tertiary } \\
\text { hospital }\end{array}$ & Not stated & $\begin{array}{l}\text { HIV } \\
\text { positive } \\
\text { patients }\end{array}$ & 93 & $\begin{array}{l}\text { Both gender } \\
\text { (all age } \\
\text { group) }\end{array}$ & $86.2 \%$ & Nil & $\begin{array}{l}\text { There is no association } \\
\text { between increasing or } \\
\text { decreasing CD4 } \\
\text { T-count and } \\
\text { parasitaemia. }\end{array}$ & HAART \\
\hline $\begin{array}{l}\text { Omoti } \\
\text { (Omoti CE, } \\
\text { Ojide CK, } \\
\text { Lofor PV, } \\
\text { Eze E, \& Eze } \\
\text { JC, 2013) } \\
\text { Benin City, } \\
\text { Nigeria }\end{array}$ & $\begin{array}{l}\text { Tertiary } \\
\text { hospital }\end{array}$ & Not stated & $\begin{array}{l}\text { HIV } \\
\text { positive } \\
\text { patients }\end{array}$ & 342 & $\begin{array}{l}\text { Both } \\
\text { gender/Adul } \\
\text { ts }\end{array}$ & $74.3 \%$ & Nil & $\begin{array}{l}\text { New cases of malaria } \\
\text { parasitaemia progress } \\
\text { with HIV clinical stage. }\end{array}$ & Nil \\
\hline $\begin{array}{l}\text { Onyenekwe } \\
\text { (Onyenekwe } \\
\text { CC et al., } \\
\text { 2007) } \\
\text { Nnewi, } \\
\text { Nigeria }\end{array}$ & $\begin{array}{l}\text { Tertiary } \\
\text { hospital }\end{array}$ & $\begin{array}{l}\text { Prospective } \\
\text { cohort study }\end{array}$ & $\begin{array}{l}\text { HIV } \\
\text { positive } \\
\text { patients }\end{array}$ & 196 & $\begin{array}{l}\text { Both gender } \\
\text { (all age } \\
\text { group) }\end{array}$ & $18.9 \%$ & $10.6 \%$ & $\begin{array}{l}\text { High co-infection } \\
\text { prevalence was } \\
\text { reported among } \\
\text { symptomatic HIV } \\
\text { positive individuals } \\
\text { three times higher than } \\
\text { in the asymptomatic. }\end{array}$ & Nil \\
\hline $\begin{array}{l}\text { Sanyaolu } \\
\text { (Sanyaolu } \\
\text { AO et al., } \\
\text { 2013) }\end{array}$ & $\begin{array}{l}\text { Secondar } \\
\text { y hospital }\end{array}$ & $\begin{array}{l}\text { Cross-section } \\
\text { al }\end{array}$ & $\begin{array}{l}\text { HIV } \\
\text { positive } \\
\text { patients }\end{array}$ & 1080 & Both gender & $47.7 \%$ & $25.8 \%$ & $\begin{array}{l}\text { High cases of malaria } \\
\text { and anaemia were } \\
\text { reported among HIV } \\
\text { seropositive patients. }\end{array}$ & Nil \\
\hline
\end{tabular}




\begin{tabular}{|c|c|c|c|c|c|c|c|c|c|}
\hline $\begin{array}{l}\text { Lagos, } \\
\text { Nigeria }\end{array}$ & & & & & & & & & \\
\hline $\begin{array}{l}\text { Unata (Unata } \\
\text { IM, Bunza } \\
\text { NM, Ashcroft } \\
\text { OF, } \\
\text { Abubakar A, } \\
\text { \& Faruk N, } \\
\text { 2015) } \\
\text { Sokoto, } \\
\text { Nigeria }\end{array}$ & $\begin{array}{l}\text { Tertiary } \\
\text { hospital }\end{array}$ & Not stated & $\begin{array}{l}\text { HIV } \\
\text { positive } \\
\text { patients }\end{array}$ & 159 & Both gender & $45.4 \%$ & Nil & $\begin{array}{l}\text { A high prevalence of } \\
\text { malaria was reported } \\
\text { among females and } \\
\text { married individuals. }\end{array}$ & $\begin{array}{l}\text { Antimalari } \\
\text { a/cotrimox } \\
\text { azole }\end{array}$ \\
\hline $\begin{array}{l}\text { Wariso } \\
\text { (Wariso KT } \\
\text { \& Nwauche } \\
\text { CA, 2011) } \\
\text { Port } \\
\text { Harcourt, } \\
\text { Nigeria }\end{array}$ & $\begin{array}{l}\text { Tertiary } \\
\text { hospital }\end{array}$ & Not stated & $\begin{array}{l}\text { HIV } \\
\text { positive } \\
\text { patients }\end{array}$ & 300 & $\begin{array}{l}\text { Both } \\
\text { gender/Adul } \\
\text { ts }\end{array}$ & $26.5 \%$ & Nil & $\begin{array}{l}\text { A slightly higher } \\
\text { prevalence of malaria } \\
\text { was reported among } \\
\text { males. }\end{array}$ & Nil \\
\hline
\end{tabular}

\section{Results}

Data obtained from the reviewed literature selected from all the geopolitical zone was shown in (Table 1) above. The variables were coded and analysed using SPSS version 25.0. The data analysis indicated that the mean \pm SD among the HIV-malaria co-infected group and the study participants who were HIV positive alone in all the geo-political zone are $36.6 \pm 25.5$ and $19.5 \pm 15.3$, respectively. The overall mean prevalence of HIV-malaria co-infection was $36.6 \%$ (Table 2). The reviewed literature also reported the use of Highly Active Antiretroviral Therapy (HAART), which is associated with a reduced mean positive prevalence of $31.26 \%$.

Table 2. Descriptive statistics for HIV-malaria co-infected group and the HIV-malaria negative group in Nigeria, as reported in the literature

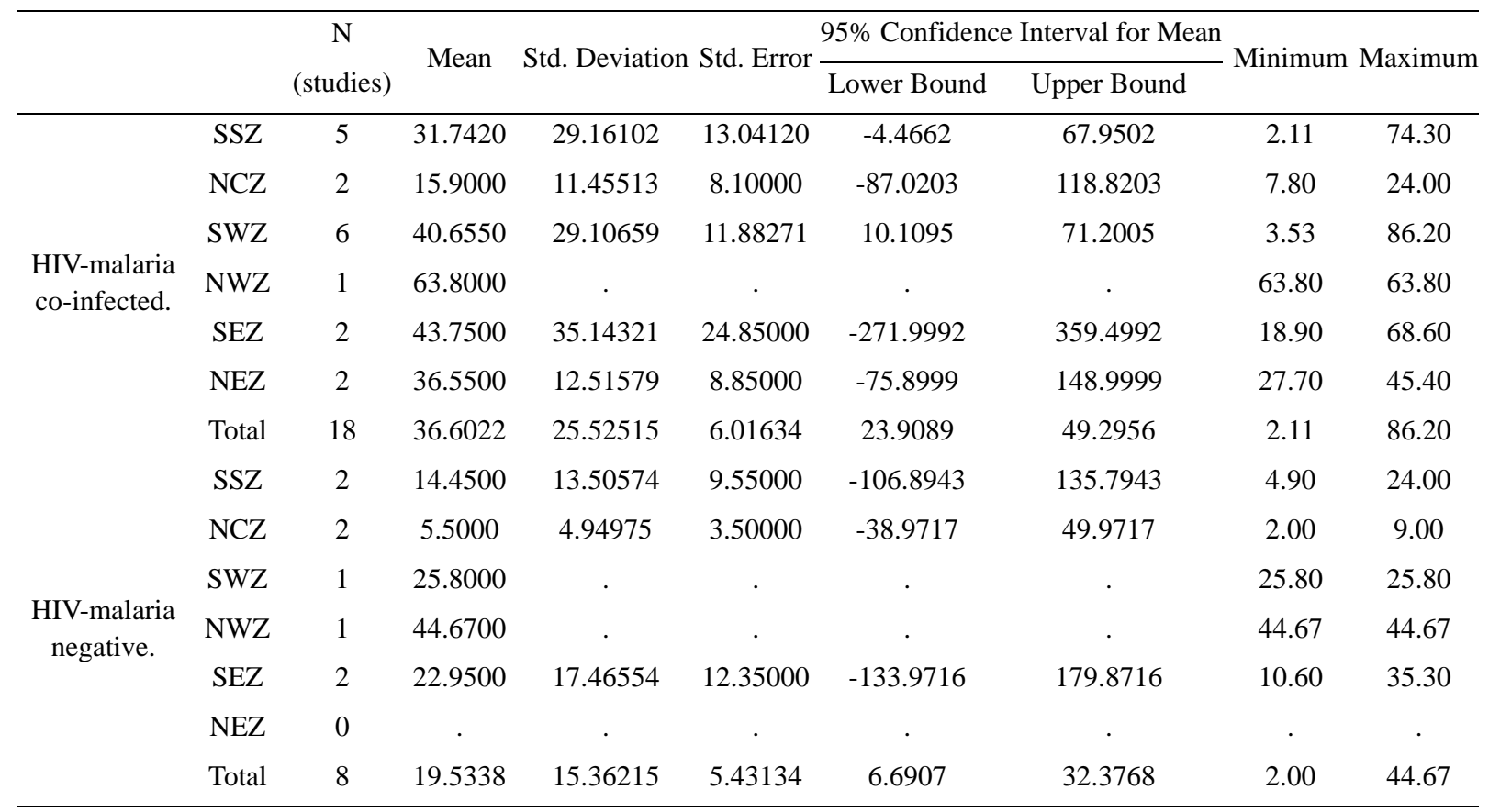

Key: SSZ: South-South Zone. NCZ: North Central Zone. SWZ: South West Zone. NWZ: North West Zone. SEZ: South East Zone. NEZ: North East Zone. 
The highest mean prevalence of $63.7 \%$ was reported among HIV patients co-infected with malaria in the north-west zone (NWZ) compared to $44.67 \%$ reported among HIV-malaria negative patients in the same region. However, the lowest mean prevalence of $16 \%$ and $5.5 \%$ were found in a similar group in the north-central zone (NCZ) Nigeria, respectively. This may be because only a small proportion of the study selected for review, $11.1 \%$ were conducted in the NCZ. Interestingly there is a strong correlation of 1.0 and 0.794 between the two groups recruited in the study in association with the HIV prevalence, although the association is not statistically significant (Table 2).

The mean prevalence of HIV-malaria co-infection is the highest $86.2 \%$ among patients on antimalarial treatment (Olaniran et al., 2012). A proportion of the reviewed literature also reported the use of HAART, which is associated with reduced mean positive prevalence of $31.26 \%$, far higher than $2.1 \%$ that was reported by (Akinbo et al., 2009) and lower than the $86.2 \%$ documented by (Olaniran et al., 2012) in 2012. However, a relatively higher mean prevalence of $37.88 \%$ was observed among patients that were not using any treatment procedure, as reported in the studies selected for this literature review (Figure 1). Among HIV seropositive individuals, the use of HAART has shown to improve host immunity (Willemot \& Klein, 2004), which might be responsible for the reduced prevalence reported among patients on HAART compared to patients without any treatment procedure in this literature review.

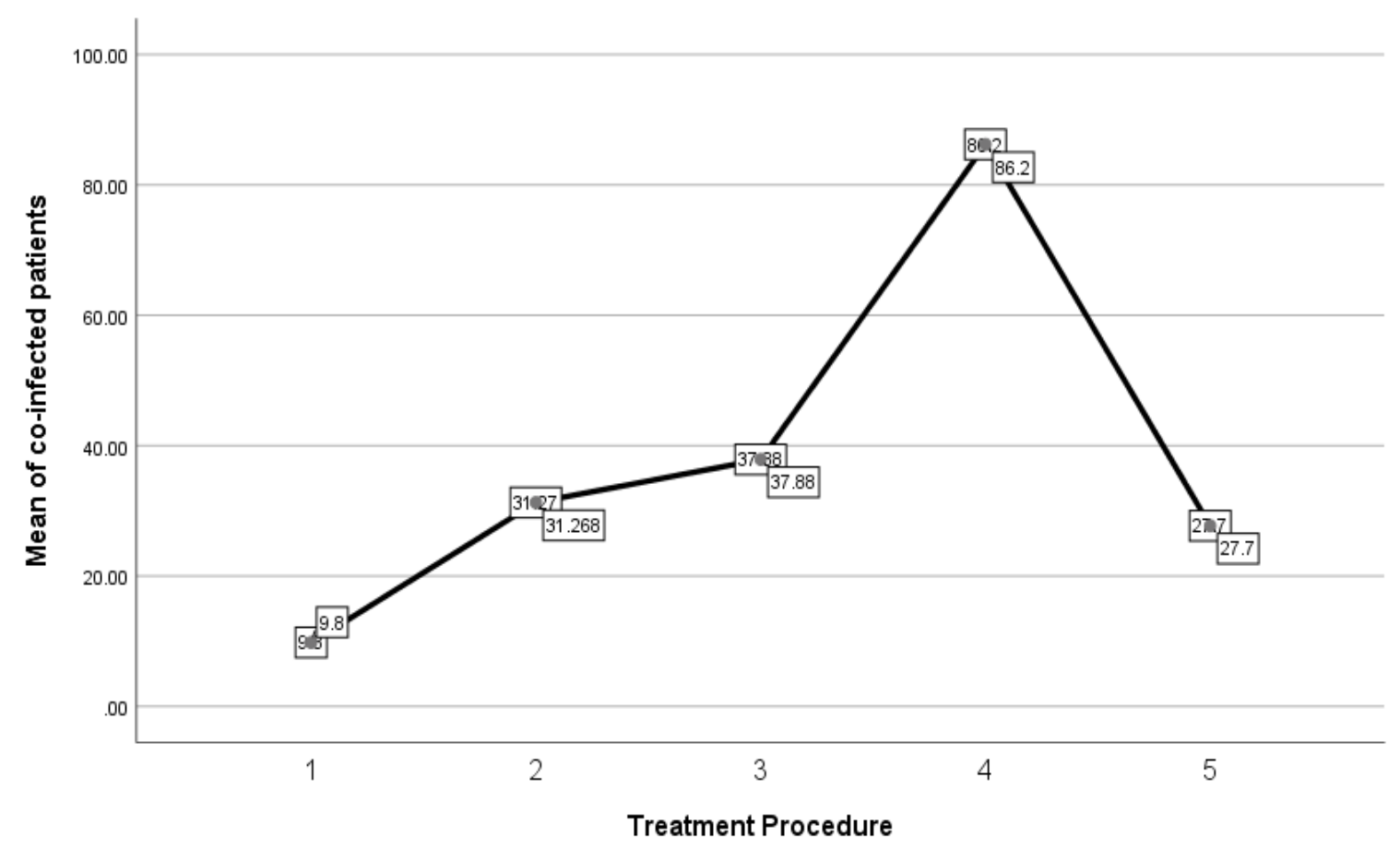

Association between treatment and HIV/malaria co-infection.

Figure 1. Shows an association between treatment and HIV-malaria co-infection

The test for the homogeneity of variance revealed that there is no significant association between both HIV patients that were co-infected with malaria and the HIV-malaria negative group and the mean, median, and adjusted degree of freedom (Figure 1). The analysis of variance between the two groups and the mean prevalence of HIV co-infected patients indicated no significant association, 0.769 and 0.351 for HIV-malaria co-infected group and the participants that were only HIV positive.

\section{Discussion}

Annually, HIV and malaria are responsible for over four million deaths globally (Akinbo FO et al., 2009). There is also a high risk of public health concern of HIV-malaria co-infection interaction in Nigeria, a region where both diseases overlap. Findings from this review of the literature revealed that studies conducted on HIV malaria co-infection in Nigeria hardly document the study design used in the research study and the research settings where the studies were conducted. This review also established that semi-urban regions where primary and secondary 
hospital settings were situated with the possibility of high HIV-malaria co-infection interaction have been repeatedly neglected, as previously reported (Berg, Patel, Langeland, \& Blomberg, 2008), (Nakanjako et al., 2011). Similarly, some of the study design employed are either not suitable or inappropriate (Iroezindu et al., 2012), (Sanyaolu et al., 2013).

\section{Conclusion}

This review of the literature utilized 18 studies selected in Nigeria between ten years. The literature showed a relatively high mean prevalence of 36.6\% HIV-malaria co-infection among HIV seropositive patients in Nigeria. This indicates that HIV positive individuals in the NCZ, as a result of a suppressed immune system, are at higher risk of malaria co-infection. This review highlights the urgent need for regular malaria screening and testing among PLWHA to prevent mortality in HIV-malaria co-infected patients.

\section{Ethics Approval and Consent to Participate}

Not applicable.

\section{Consent for Publication}

Not applicable.

\section{Availability of Data and Materials}

Not applicable.

\section{Funding}

Not applicable.

\section{Authors Contributions}

Relevant literature was reviewed by O. S. Alaofin, who wrote the manuscript. K. Naidoo helped in drafting the manuscript. The manuscript was edited and approved by the authors O.S. Alaofin and K. Naidoo.

\section{Acknowledgements}

I want to acknowledge Professor Nancy Lea Eik-Nes, University of Trondheim, Norway, for reading through this manuscript out of her busy schedule.

\section{Limitations}

An equal proportion of the research study were not reviewed across the zones, together with a small sample size in almost all the reviewed literature are limitations that weaken the internal validity of this literature review.

\section{Competing Interests Statement}

The authors declare that they have no conflict of interest regarding the publication of this literature review.

\section{References}

Abu-Raddad, L. J., Patnaik, P., \& Kublin, J. G. (2006). Dual infection with HIV and malaria fuels the spread of both diseases in sub-Saharan Africa. Science, 314(5805), 1603-1606. https://doi.org/10.1126/science.1132338

Akinbo, F. O., Anate, P. J., Akinbo, D. B., Omoregie, R., Okoosi, S., \& Abdulsalami, A. (2016). Prevalence of malaria among HIV patients on highly active antiretroviral therapy in Kogi State, North Central Nigeria. Annals of Nigerian Medicine, 10(1), 11-15. https://doi.org/10.4103/0331-3131.189802

Akinbo, F. O., Okaka, C. E., Omoregie, R., Mordi, R., \& Igbinuwen, O. (2009). Prevalence of malaria and anaemia among HIV-infected patients in Benin City, Nigeria. New Zealand Journal of Medical Laboratory Science, 63(3), 78-80. Retrieved from http://search.ebscohost.com/login.aspx?direct=true $\& d b=c 78 h \& A N=105245927 \&$ site=ehost-live

Akinbo, F. O., \& Omoregie, R. (2012). Plasmodium falciparum infection in HIV-infected patients on highly active antiretroviral therapy (HAART) in Benin City, Nigeria. Journal of Research In Health Sciences, 12(1), 15-18. Retrieved from http://search.ebscohost.com/login.aspx?direct=true \&db=mnh\&AN=22888709\&site=ehost-live

Akinbo, F. O., Omoregie, R., Dixon, L., Brown, K., Wilson, R., \& Eraifej, M. (2013). Co endemicity of Plasmodium falciparum and HIV infections in treated patients is uncorrelated. J Bacteriol Parasitol, 4(4), 175 181. http://dx.doi.org/110.4172/2155-9597.1000176

Ako-Nai, A. K., Ebhodaghe, B. I., Osho, P. O., Adejuyigbe, E. A., Adeyemi, F. M., Ikuomola, A. A., \& Kassim, O. 
O. (2013). The epidemiology of HIV seropositive malaria infected pregnant women in Akure Metropolis, Southwestern Nigeria. Annals of Tropical Medicine \& Public Health, 6(5), 519-525. https://doi.org/10.4103/1755-6783.133703

Berg, A., Patel, S., Aukrust, P., David, C., Gonca, M., Berg, E. S., . . Langeland, N. (2014). Increased Severity and Mortality in Adults Co-infected with Malaria and HIV in Maputo, Mozambique: A Prospective Cross-Sectional Study PLoS ONE, 9(2), e88257. https://doi.org/10.1371/journal.pone.0088257

Berg, A., Patel, S., Langeland, N., \& Blomberg, B. (2008). Falciparum malaria and HIV-1 in hospitalized adults in Maputo, Mozambique: does HIV-infection obscure the malaria diagnosis? Malaria Journal, 7(252), 1-8. https://doi.org/10.1186/1475-2875-7-252

Carnivale, P., \& Mouchet, J. (2011). Prospect of malaria control in Howell. International Journal for Parasitology, $17(1), 156-165$.

Cuadros, D. F., \& García-Ramos, G. (2012). Variable Effect of Co-infection on the HIV Infectivity: Within-host dynamics and epidemiological significance. Theoretical Biology and Medical Modelling, 9(9), 1-19. https://doi.org/10.1186/1742-4682-9-9

Dada, E. O. (2015). Prevalence of Malaria and Co-infection with Human Immuno-Deficiency Virus (HIV) in Selected Areas of Ondo State, Nigeria. International Journal of Tropical Disease \& Health, 8(1), 34-39. https://doi.org/10.9734/IJTDH/2015/16987

Edet, U. O., Ebana, R. U. B., Etok, C. A., \& Nwamuo, L. C. (2016). Prevalence of Human Immunodeficiency Virus and Plasmodium falciparum Dual Infection amongst Residents of Kaduna South in North Western Nigeria. International Journal of TROPICAL DISEASE \& Health, 7(1), 1-7. https://doi.org/10.9734/IJTDH/2016/25961

Eki-Udoko, F. E., Sadoh, A. E., Ibadin, M. O., \& Omoigberale, A. I. (2017). Prevalence of congenital malaria in newborns of mothers co-infected with HIV and malaria in Benin city. Infectious Diseases, 49(8), 609-616. https://doi.org/10.1080/23744235.2017.1312667

Federal Republic of Nigeria. (2005). National Antimalarial Treatment Policy. Federal Republic of Nigeria. Federal Ministry of Health National Malaria and Vector Control Division Abuja-Nigeria. Retrieved from

Focà, E., Odolini, S., Brianese, N., \& Carosi, G. (2012). Malaria and Hiv in Adults: when the Parasite Runs into the Virus. Mediterranean Journal of Hematology \& Infectious Diseases, 4(1), 1-9. https://doi.org/10.4084/mjhid.2012.032

Goselle, O. N., Onwuliri, C. O. E., \& Onwuliri, V. A. (2009). Malaria infection in HIV/AIDS patients and its correlation with packed cell volume (PCV). Journal of Vector Borne Diseases, 46(3), 205-211. Retrieved from http://search.ebscohost.com/login.aspx?direct=true $\& d b=m n h \& A N=19724084 \&$ site=ehost-live

Gossele, O. N., Onwuliri, C. O. E., \& Onwuliri, V. A. (2007). Malaria and Effect of Malaria Parasitaemia on Albumin Level Among HIV/AIDS-Patients in Jos, Nigeria. Journal of Medical Sciences, 7(7), 1187-1191. https://doi.org/10.3923/jms.2007.1187.1191

Hochman, S., \& Kim, K. (2009). The Impact of HIV and Malaria Coinfection: What Is Known and Suggested Venues for Further Study. Interdisciplinary Perspectives on Infectious Diseases, 1-8. https://doi.org/10.1155/2009/617954

Iroezindu, M. O., Agaba, E. I., Okeke, E. N., Daniyam, C. A., Obaseki, D. O., Isa, S. E., \& Idoko, J. A. (2012). Prevalence of malaria parasitaemia in adult HIV-infected patients in Jos, North-central Nigeria. Nigerian Journal of Medicine: Journal of The National Association of Resident Doctors Of Nigeria, 21(2), 209-213. Retrieved

from http://search.ebscohost.com/login.aspx?direct=true \&db=mnh\&AN=23311193\&site=ehost-live

Izuka, E. O., Ugwu, E. O., Obi, S. N., Ozumba, B. C., Nwagha, T. U., \& Obiora-Izuka, C. E. (2017). Prevalence and predictors of placental malaria in human immunodeficiency virus-positive women in Nigeria. Nigerian Journal Of Clinical Practice, 20(1), 31-36. https://doi.org/10.4103/1119-3077.180077

Jegede, F. E., Oyeyi, T. I., Abdulrahman, S. A., Mbah, H. A., Badru, T., Agbakwuru, C., \& Adedokun, O. (2017). Effect of HIV and malaria parasites co-infection on immune-hematological profiles among patients attending anti-retroviral treatment (ART) clinic in Infectious Disease Hospital Kano, Nigeria. PLoS ONE, 12(3), 1-17. https://doi.org/10.1371/journal.pone.0174233

Khoo, S., Back, D., \& Winstanley, P. (2005). The potential for interactions between antimalarial and antiretroviral 
drugs. AIDS, 19(10), 995-1005. https://doi.org/10.1097/01.aids.0000174445.40379.e0

Laufer, M. K., \& Plowe, C. V. (2007). The Interaction between HIV and Malaria in Africa. Current Infectious Disease Reports Tropical and Travel Medicine, 9(1), 47-54. https://doi.org/10.1007/s11908-007-0022-3

Mukandavire, M., Gumel, A. B., Garira, W., \& Tchuenche, J. M. (2009). Mathematical analysis of a model for HIV-malaria co-infection. Mathematical Biosciences and Engineering, 6(2), 333-362. https://doi.org/10.3934/mbe.2009.6.333

NACA. (2015). Federal Republic of Nigeria, Global AIDS Response: National Agency for Control of AIDS. Country Progress Report Nigeria.

NACA. (2017). National Strategic Framework on HIV and AIDS: National Agency for Control of AIDS 2017 -2021. Retrieved 29 Aug, $2018, \quad$ from https://www.childrenandaids.org/sites/default/files/2017-11/NATIONAL-HIV-AND-AIDS-STRATEGIC-F RAMEWORK

Nakanjako, D., Kiragga, A. N., Castelnuovo, B., Kyabayinze, D. J., \& Kamya, M. R. (2011). Low prevalence of Plasmodium falciparum antigenaemia among asymptomatic HAART treated adults in an urban cohort in Uganda. Malaria Journal, 10(66), 1-5. https://doi.org/10.1186/1475-2875-10-66

Ojurongbe, O., Oyeniran, O. A., Alli, O. A. T., Taiwo, S. S., Ojurongbe, T. A., Olowe, A. O., . . Adeyeba, O. A. (2014). Prevalence of Plasmodium falciparum Parasitaemia and Its Correlation with Haematological Parameters among HIV-Positive Individuals in Nigeria. Journal of Tropical Medicine, 2014(161284), 1-7. https://doi.org/10.1155/2014/161284

Olaniran, O., Ojurongbe, O., Hassan-Olajokun, R., Akindele, A. A., Japhet, M. O., Bolaji, S. O., \& Adedokun, A. (2012). The study of asymptomatic Plasmodium falciparum in humans infectedwith immunodeficiency virus in Ile-Ife, Nigeria. Microbiology Research, 3(1), 1-4. https://doi.org/10.4081/mr.2012.e1

Omoti, C. E., Ojide, C. K., Lofor, P. V., Eze, E., \& Eze, J. C. (2013). Prevalence of parasitemia and associated immunodeficiency among HIV-malaria co-infected adult patients with highly active antiretroviral therapy. Asian Pacific Journal of Tropical Medicine, 6(2), 126-130. https://doi.org/10.1016/S1995-7645(13)60007-3

Onifade, A. K., Akanni, E. O., \& Mewoyeka, O. O. (2007). Incidence of Malaria Infection among Human Immunodeficiency Virus Patients in Ondo State, Nigeria. Middle-East Journal of Scientific Research, 2(2), 48-53. Retrieved from https://doi.org/53f247de240cf272810e272814cbd272818a.pdf

Onyenekwe, C., Ukibe, N., Meludu, S., Ifeanyi, M., Ezeani, M., Onochie, A., . . . Ilika, A. (2008). Possible biochemical impact of malaria infection in subjects with HIV co-infection in Anambra state, Nigeria. Journal Of Vector Borne Diseases, 45(2), 151-156. Retrieved from https://www.ncbi.nlm.nih.gov/pubmed/18592844

Onyenekwe, C. C., Ukibe, N., Meludu, S. C., Ilika, A., Aboh, N., Ofiaeli, N., . . Onochie, A. (2007). Prevalence of malaria as co-infection in HIV-infected individuals in a malaria endemic area of southeastern Nigeria. Journal of Vector Borne Diseases, 44(4), 250-254. Retrieved from:https://www.ncbi.nlm.nih.gov/pubmed/18092531.

Salako, L., \& Obi, C. C. (1997). Malaria the Unending Saga. Keynote Address in: Coping with Treatment Failures in Malaria (pp. 13-25). Lagos: Mayer and Baker.

Sanyaolu, A. O., Fagbenro-Beyioku, A. F., Oyibo, W. A., Badaru, O. S., Onyeabor, O. S., \& Nnaemeka, C. I. (2013). Malaria and HIV co-infection and their effect on haemoglobin levels from three healthcare institutions in Lagos, southwest Nigeria. African Health Sciences, 13(2), 295-300. https://doi.org/10.4314/ahs.v13i2.14

The Global Fund. (2016). List of HIV diagnostic test kits and equipments classified according to the Global Fund quality assurance policy. Version 14. 2017 March 31. Vernier: The Global Fund 2016. Retrieved June 9, 2017, from https://www.theglobalfund.org/media/5878/psm_productshivwho_list_en.pdf

UNAIDS. Status of the Global HIV Epidemic 2008. Retrived from http://data.unaids.org/pub/GlobalReport/2008/jc1510_2008_global_report_pp29_62_en.pdf. Accessed 5 June 2017. Retrieved from

UNAIDS. (2003). Global Fact Sheet. United Nations Programme on HIV/AIDS.

UNAIDS. (2016). Country HIV and AIDS estimates, Joint United Nations Programme on HIV and AIDS.

UNAIDS. (2017). Data Book. Joint United Nations Programme on HIV and AIDS. Retrieved 29 Aug, 2018, from 
http://www.unaids.org/sites/default/files/media_asset/20170720_Data_book_2017_en

Unaids Facts Sheet 2014, Global Statistics.

Unata, I. M., Bunza, N. M., Ashcroft, O. F., Abubakar, A., \& Faruk, N. (2015). Prevalence of Malaria Parasites among HIV/AIDS Patients Attending HIV Clinic in Usmanu Danfodiyo University Teaching Hospital and Sokoto State Specialist Hospital, Sokoto, Nigeria. International Journal of Novel Research in Life Sciences, 2(2), 39-43. Retrieved from http://www.noveltyjournals.com/

Van geertruyden, J. P. (2014). Interactions between malaria and human immunodeficiency virus anno 2014. Clinical Microbiology \& Infection, 20(4), 278-285. https://doi.org/10.1111/1469-0691.12597

Warhurst, D. C., \& Williams, J. E. (1996). Laboratory diagnosis of malaria. J. Clin Pathol, 49(7), 533-538. https://doi.org/10.1136/jcp.49.7.533

Wariso, K. T., \& Nwauche, C. A. (2011). The Prevalence of Malaria Antigen In The Serum of HIV Seropositive Patients In Port Harcourt. The Nigerian Health Journal, 11(4), 120-122. Retrieved from: https://www.ajol.info/index.php/nhj/article/viewFile/90537/79955

Whitworth, J., Morgan, D., Quigley, M., Smith, A., Mayanja, B., \& Eotu, H. (2000). Effect of HIV 1 and increasing immunosuppression on malaria parasitaemia and clinical episodes in adults in rural Uganda: A cohort study. Lancet, 356(9235), 1051-1056. https://doi.org/10.1016/S0140-6736(00)02727-6

WHO. (2012). World Malaria Report. World Health Organization, Geneva.

WHO. (2016a). HIVIAIDS Fact sheet. World Health Organization.

WHO. (2016b). Malaria Fact sheet. World Health Organization. World Malaria Report.

WHO. (2016c). Malaria in HIV/AIDS patients. World Health Oganization.

WHO. (2017). World Malaria Report. World Health Organization. Geneva; 2017. License: CC BYNC-SA 3.0 IGO. Retrieved from http://www.who.int/malaria/publications/world-malariareport-2017/report/en/

Willemot, P., \& Klein, M. B. (2004). Prevention of HIV-associated opportunistic infections and diseases in the age of highly active antiretroviral therapy. Expert Review of Anti-infective Therapy, 2(4), 521-532. https://doi.org/10.1586/14787210.2.4.521

World Health Organization. (2005). Malaria and HIV Interactions and their Implications for Public Health Policy. World Health Organization Geneva, Switzerland. Retrieved from

UNAIDS. (2013). United Nations Programme on HIV/AIDS report on the global AIDS epidemic 2013. Global report 2013: UNAIDS Web site. Retrieved from http://www.unaids.org/en/media/unaids/contentassets/documents/epidemiology/2013/gr2013/UNAIDS_Glo bal_Report_2013_en.pdf

\section{Copyrights}

Copyright for this article is retained by the author(s), with first publication rights granted to the journal.

This is an open-access article distributed under the terms and conditions of the Creative Commons Attribution license (http://creativecommons.org/licenses/by/4.0/). 